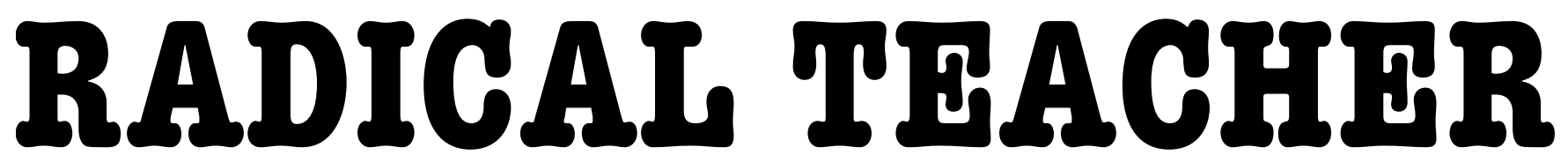

A SOCIALIST, FEMINIST, AND ANTI-RACIST JOURNAL ON THE THEORY AND PRACTICE OF TEACHING

\title{
A Radical Critique of the Learning Outcomes Assessment Movement
}

by Michael Bennett and Jacqueline Brady

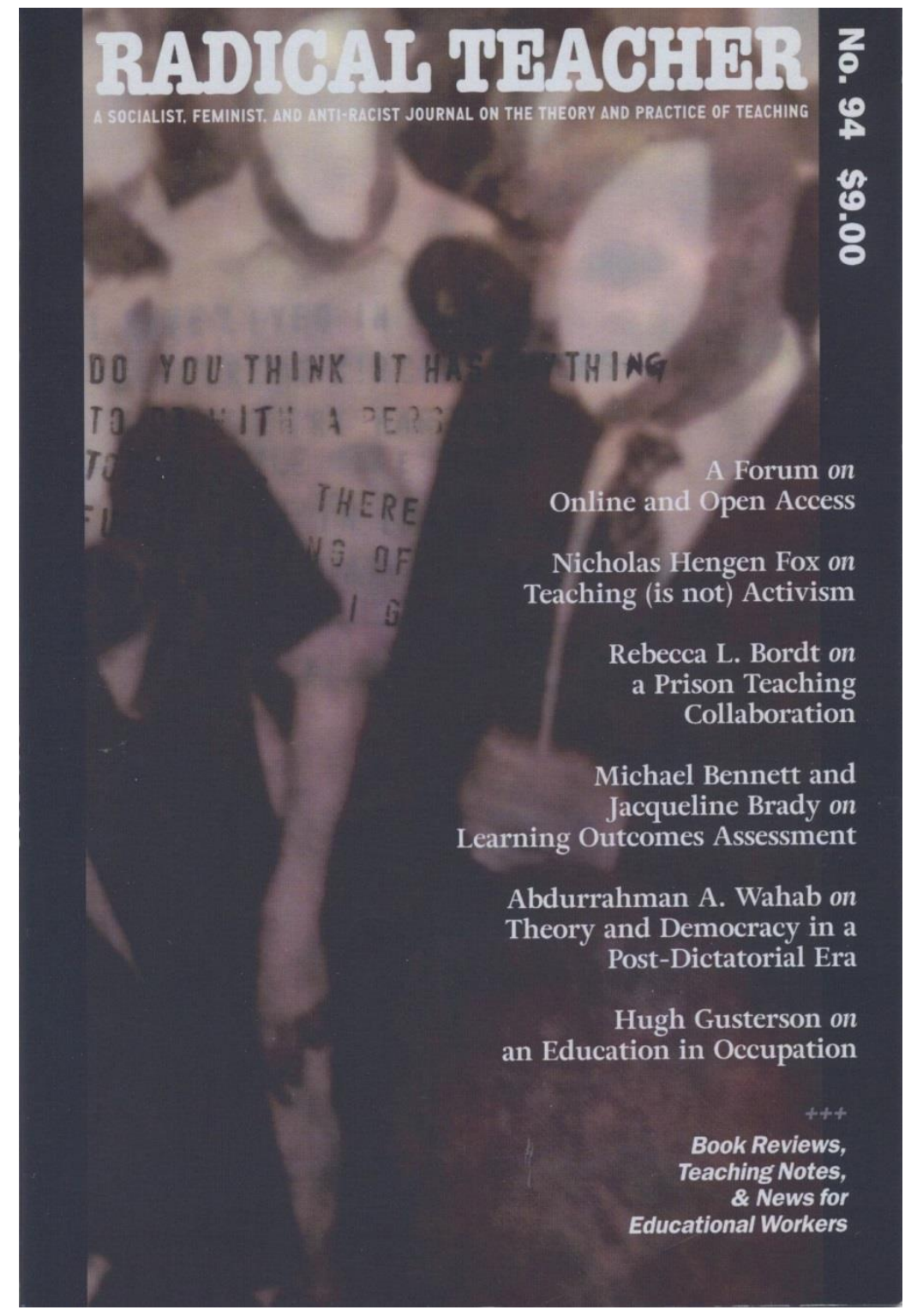


$T$ he Learning Outcomes Assessment (LOA) movement seems rather innocuous. Teachers and administrators at colleges and universities are asked to articulate the goals, objectives, measures, and outcomes of the educational process at every level: from the classroom to the department to the institution as a whole. Educators engage in this process with the help of curriculum mapping or educational matrices or a host of other tools and templates provided by any number of readily available frameworks (see the website of the National Institute for Learning Outcomes Assessment for many examples). The information gathered is then used to evaluate curricula, programs, instructors, and institutions for purposes of internal review and external evaluation.

And yet we insist that a radical perspective on the LOA movement can be summarized in one word: RESIST! Why resist what appears, on the surface, to be such a benign process? Our radical critique of LOA goes beneath the surface level to historicize the movement, examine its socio-political contexts, and ultimately suggest that the movement provides an ideological smokescreen acting as a distraction from the real problems with U.S. higher education.

First, we need to distinguish between the LOA movement and legitimate faculty-driven efforts at curriculum development, best assessment practices, and delineate three types of learning outcomes that are the result of: 1) one lesson; 2) an entire course; and 3) a whole program of study. According to Hussey and Smith, the first two types are basically mere changes in vocabulary from "lesson plan" and "course content" to "learning outcomes." They argue that the focus on learning outcomes becomes less effective as you move beyond the individual lesson toward a full course, until it is basically meaningless when used to articulate outcomes for whole programs of study.

The use of the term "learning outcome" for what is to be included in a whole program of study leading to a qualification such as a degree constitutes a misuse. In short, the further away from the student and the teacher in a classroom, the more remote, generalized, and irrelevant statements of learning outcomes become (114). Because engaged learning is so complex, the level at which the LOA movement most often is focused renders meaningful assessment impossible. Outcomes become a "device for monitoring and auditing" educators, rather than a tool of teaching and learning (Hussey and Smith, "The Uses" 357). Thus Hussey and Smith conclude that "The focus on intended learning outcomes . . . has more to do with administrative and regulatory necessity rather than education in the sense of students' deep engagement with curriculum" ("The Uses" 358).

In the United States, the roots of the LOA movement, as opposed to engaged learning practices, can be traced LOA is really another manifestation for the standards movement, which emerged alongside the efficiency movement at the turn of the $20^{\text {th }}$ century. By the first decade of the last century, business models, rhetoric, and course evaluation. Trevor Hussey and Patrick Smith back to Taylorism and theories of scientific management.

ideology had so saturated the field of $\mathrm{K}-12$ education that educators themselves began proposing that schools should run as efficiently as factories. A social efficiency movement in education took firm hold, with influential proponents such as William C. Bagley, who wrote the textbook Classroom Management in 1907 so that teachers, educators, and professionals in the field might better apply the principles of scientific management to their workspaces. His book was followed by Franklin Bobbit's The Curriculum, in 1918. Drawing his influence from business and economic sectors, Bobbit-the inventor of Curriculum Theory-argued that schools, like businesses, should be efficient, eliminate waste, and focus on outcomes to the degree that the curriculum must be useful in shaping students into adult workers. Along with Frederick Winslow Taylor, Bobbit believed that efficient outcomes depended on centralized authority and precise, top down instruction for all tasks performed. Teachers were expected to acquiesce in the outside knowledge of efficiency experts-administrators and professors of education. Thus, curriculum was conceived of as a normalizing device and instrument of social regulation, one that would help control the working class so that the United States could better compete with German production. In the last century's efficiency movement, as in the current LOA movement, teachers were conceived of as passive receptacles, rather than primary players in the process of education (Eisner 347).

In the contemporary context, assessment advocate Peter Ewell argues that LOA transferred from the mainstream corporate world to the realm of higher

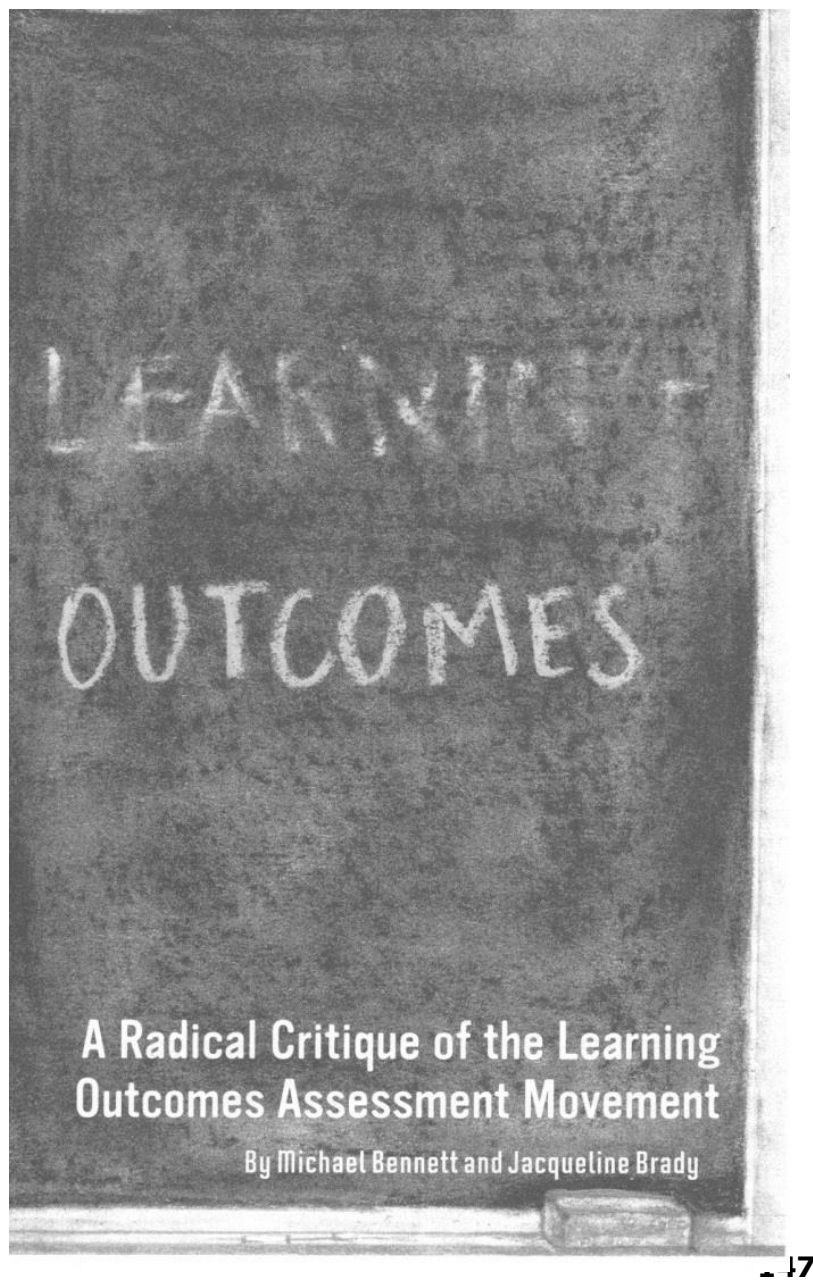

RADICAL TEACHER 
education starting in the 1980s when the "burgeoning competency movement in corporate training... [stimulated] accreditation's interest in examining student learning outcomes" (3) as part of the effort to "develop a ' $21^{\text {st }}$ Century' workforce" (2). Rising with the tide of late twentieth century neo-conservatism/neo-liberalism, the discourse of LOA circulated from private think tanks and non-governmental organizations, such as the conservative American Council of Trustees and Alumni (ACTA) and its neo-liberal cousin the Committee for Economic Development (CED), to the halls of Congress as part of the No Child Left Behind (NCLB) Act and Congressional Hearings on Assuring Quality and Accountability in Postsecondary Education and the White House, most famously in the Spellings Report (2005), but also in various other Department of Education pronouncements made over the past ten years.

ACTA's report Can College Accreditation Live Up to its Promise? makes the link between outcomes assessment and accreditation when it claims that accrediting agencies had historically focused only on inputs rather than outcomes: "Rather than ensuring education quality, accreditation merely verifies that a school has what accreditors regard as the proper inputs and procedures" (Leef and Burris 2). This leads to the conclusion that accrediting agencies should be limited or abolished unless they accept ACTA's agenda:

First, the connection between eligibility for government student aid and accreditation should be severed. Second, trustees should become more active in the accreditation process. Third, state governments should bring needed competition to the field of accreditation . . . Finally, the accreditation associations should start acting in a manner more akin to business consultants . . .(Leef and Burris 3).

ACTA at least has the virtue of being clear: the business of higher education is business; teachers and students should be subject to the same disciplinary measures as any other workers and their products. Frederick Taylor would be proud.

The dictates of capital still generate the discourse of outcomes assessment, which is characterized by the buzzwords and practices of neo-conservative/neo-liberal ideology. The phrases that recur include educational consumers, target market, corporate management perspective, competitiveness, value, efficiency, productivity, regulatory burden, stakeholder demands, return on investment, entrepreneurship, and value-added education. $^{1}$ Institutions of higher learning and the education process become just like factories that manufacture and sell products.

To see how this discourse circulates, here is Rep. Thomas E. Petri of the House Subcommittee on $21^{\text {st }}$ Century Competitiveness of the Committee of Education and the Workforce at the aforementioned Congressional hearings of 2003-2004 repeating ACTA's agenda almost word for word:
Unfortunately, accreditation, these days, has little to do with academic rigor or educational outcomes. Rather, it serves only to show that a school has the right sort of inputs. Yesterday, I introduced HR 838, the Higher Education Accrediting Agency Responsibility Act. This legislation eliminates the requirement that schools be accredited in order to receive federal student aid funds. It will help to open the accreditation process to competition.

In the names of "freedom" and "competition," this legislation directly adopts ACTA's call for a shift from inputs to outcomes. It eliminates the requirement that federal aid go to students only at accredited universities so that nonaccredited for-profit schools of suspect quality can compete for those federal funds.

\section{The phrases that recur include educational consumers, target market, corporate management perspective, competitiveness, value, efficiency, productivity, regulatory burden, stakeholder demands, return on investment . . .}

With anxiety mounting about the state of the economy and joblessness in the United States and widespread fear that North America will not be a competitive force in the globalized market, the influence of the LOA movement has successfully spread to various educational governing bodies. The National Education Association (NEA) and American Federation of Teachers (AFT) try to show their "reasonableness" by accommodating corporate interests. Accrediting agencies, as the AAUP Committee on Accreditation points out, get co-opted by governmental pressure and the lobbying efforts of for-profit pseudoschools such as the University of Phoenix and Jones International. Even some prestigious members of professional academic organizations such as the Modern Languages Association (MLA) have promoted LOA.

Gerald Graff's first column as incoming president of the MLA in 2008, "Assessment Changes Everything," illustrates the problems with liberal/centrist advocacy for the LOA movement. Graff adopts the mantra that LOA will reveal how "our own pedagogical and curricular practices contribute to the achievement gap." This argument relies on a logical fallacy common in the LOA movement (post hoc ergo propter hoc/after this therefore because of this) in assuming that if there is still an achievement gap after four or more years of schooling, then it must be caused by our teaching practices. To the extent that graduate programs teach roughly the same things and thus undergraduate curricula look generally very similar, it is not the slight variation in internal pedagogical practices that create an achievement gap but the huge structural inequalities that are everywhere evident in the widely divergent resources available to students and faculty of different classes. Blind to such structural inequalities, the conservative/neo-liberal discourse of LOA ignores the contextual situations in which 
students of different classes study, obscuring the fact that better educational opportunities require fundamental social change.

Second, Graff's centrist position erases the full historical context of the LOA movement, claiming that "the original motivations of assessment lie in legitimate progressive efforts to reform higher education from within." This may be true of certain localized assessment practices, but the original motivations for securing standardized outcomes on a national level are rooted in conservative movements for industrial scientific management. And frighteningly reactionary bipartisan forces, such as the Walton Family Foundation of Walmart and Gates Foundation of Microsoft, are still driving the current LOA movement. Through their corporate reform agenda, they are seeking to impose a mandatory exit exam for tenth graders and terminate schooling for those students who fail it.

\section{Third, Graff errs in saying "that the leadership in outcomes assessment comes from state universities and community colleges rather than from the high-prestige elites is another indication of the democratic character of the movement." Far from revealing the "democratic character" of LOA, the fact that it has been most prominent in community colleges and state universities shows that these institutions are less able to resist onerous disciplinary mechanisms than are "high-prestige elites." These are strapped institutions serving underprepared student} populations. They operate in constrained circumstances and are often subject to trustees and administrators who are more accountable to local business communities than to educators or students. Those of us who teach at nonelite institutions can readily testify that LOA is yet another way in which we are made to engage in unpaid seemingly purposeless service and bureaucratic red tape from which our more fortunate compatriots are exempt. It is also another way in which already meager funding is misdirected away from the needs of students and towards private businesses connected to the testing industry, even as classroom sizes swell and university trustees call for reducing credit hours in humanities courses.

In sum, Graff reveals a classic liberal's blindness to the ideological and socioeconomic contexts in which a practice exists by assuming a kind of level playing field on which we all operate. As we have seen, the original motivations for high stakes assessment are rooted in the undemocratic movement for social efficiency that arose from industrial scientific management, which categorized and tracked students as different kinds of workers, maintaining a strict divide among social classes. However "democratic" recent assessment practices may claim to be, the LOA movement has been and will be used for profoundly undemocratic ends-as a disciplinary mechanism for college administrations, government entities, and accrediting agencies that seek to "objectively" measure the practices of institutions with vastly different resources serving dramatically stratified student bodies.

The effects of the LOA movement can be seen most powerfully so far in the $\mathrm{K}-12$ system. In spite of the fact that there is really no evidence that the data produced by high stakes testing and the whole LOA movement is useful to teachers or beneficial to students, the results of low tests scores have been used recently by policy makers and politicians in a public siege against teachers-to vilify, shame, threaten, and fire them. Consider any of the following events of the past two years: in Rhode Island in 2010, the Superintendent of Central Falls High School decided to fire all of the school's 74 teachers if they did not comply with a program designed to improve student math scores; in Washington, D.C. in 2011, 206 teachers were fired for not sufficiently meeting the requirements for test score improvement; at an MIT conference this past December, NYC Mayor Michael Bloomberg blustered that if he had his way he would cut the number of NYC teachers in half and double the class size because this would be a better "deal" for students; and finally, just last month in New York, the DOE decided to publish the ratings (largely based on student test scores) of 18,000 NYC public school teachers.

Who benefits from this system wherein high stakes testing (read: outcomes) is used by politicians and policy makers to drum up public vitriol against teachers? Private businesses do. In primary and secondary education, low test scores have become not only a battle cry for the creation of more charter schools, but also the excuse to spend public funding on private multinational companies in the growing testing industry. The Government Accounting Office estimated that from 2002 to 2008, the amount that states would pay private multinational companies such as Harcourt Education Measurement and CTB McGraw-Hill for developing and scoring tests mandated by NCLB would fall between 1.9 and 5.3 billion dollars (Miner). Experts further suggested that additional indirect costs of things such as 
test preparation, practice exams, and testing workshops could make the final amount spent on implementing NCLB testing 8 to 15 times higher (Miner).

This misdirection of much needed resources away from students and classrooms and towards private companies is by far the most insidious result of the LOA movement in higher education today. Increasingly, in state universities and community colleges where resources are also scarce, dollars that could be much better used to defray the rapidly rising costs of student tuition instead are spent on outcomes assessment-to hire assessment experts; to create assessment measures; to analyze, score, and report on tests; to train teachers to teach towards tests; and to train administrators how to implement and advocate for more testing.

Readers of Radical Teacher know that the problems our students face with outcomes (such as graduation rates, performance on standardized measures, and obtaining good jobs) are most directly and intimately connected to

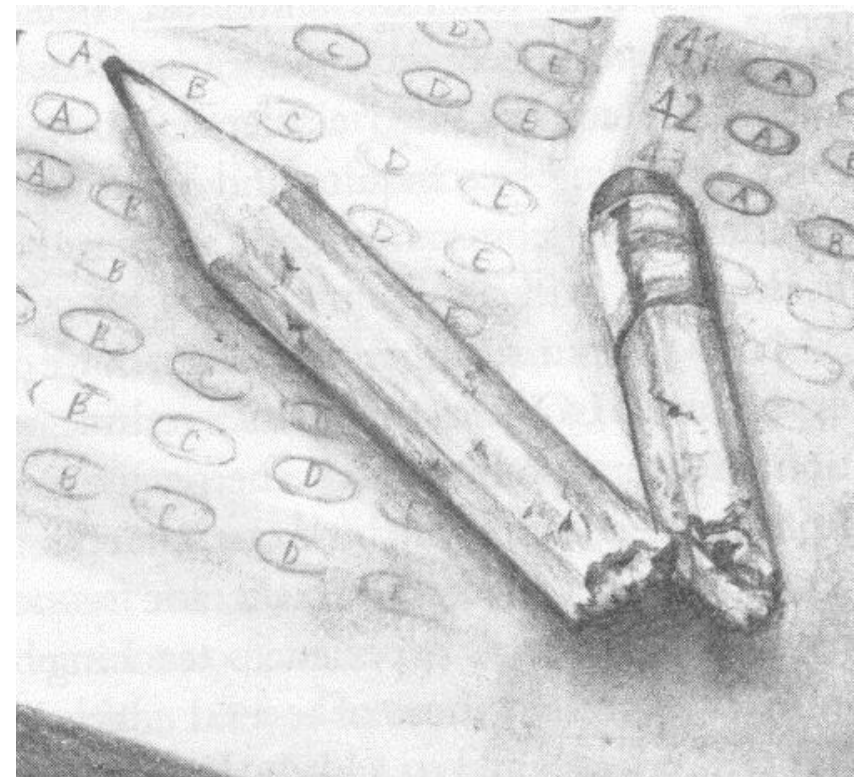

ALL DRAWINGS IN THIS ARTICLE ARE BY LEIGH CUNNINGHAM

inputs: inadequate college preparation; extensive family obligations; working at minimum wage; student debt; a corporatized educational system at odds with academic labor; inadequate healthcare and nutrition; lack of access to social, cultural, and economic capital. The actual reasons that students drop out of school, fail classes, or are unable to secure a "good job" have nothing to do with factors that can be measured by LOA. As James Pontuso and Sarranna Thornton point out, very little data produced by outcomes assessment is useful because "metrics do not exist that would allow individual colleges to assess student learning while simultaneously controlling for student aptitude, willingness and ability to do college level academic work, and other variables"(63). What separates positive from negative learning outcomes has everything to do with access to support mechanisms inside and outside the classroom and with available resources-wealth, health, time, self-confidence, and preparation. Just as SAT scores have been shown to correlate with nothing as strongly as family income, LOA is really measuring and maintaining inequality. ${ }^{2} \quad$ For there is mounting evidence suggesting that high stakes testing actually creates more inequality by increasing the gap between higher and lower achieving students, instead of closing the "race gap," the stated aim of standardized testing according to most of its advocates (See "High Stakes Testing Hurts Education" on the website for Fair Test: The National Center for Fair and Open Testing).

Thus the LOA movement is not at all a genuine attempt to decrease the "race gap," improve education, and get students onto an even playing field. It is part of the broad bipartisan campaign to privatize the system of public education. It is also a way for the wealthy to control the working class (increasingly becoming the working poor) and maintain class stratification. As outcomes assessment functions, working-class students at poor colleges and universities are required to take more high stakes exams than their peers at wealthier private and public schools. Their professors are required to compromise their own understanding of effective and thorough teaching and give up precious class time prepping students for those exams. The working-class students at these schools, who are exposed to exams that are disconnected from the content of their courses, come to see education not as deep learning, critical thinking, or understanding, but as skills and drills. In other words, now colleges and universities, not just high schools, are providing the perfect training for low-skilled jobs. And this is a good thing for the wealthy, especially those who know that the only real projected job growth in the $21^{\text {st }}$ century is that of relatively low-skilled jobs. Meanwhile students in wealthy and elite colleges and universities will largely be exempt from such high stakes testing and testing preparation and so will have more time to be groomed to compete for whatever higher paying jobs are still available. Ultimately, this whole process of LOA works not only to make education profitable for the wealthy, but also to strengthen the forces that control working-class students and to normalize the success of students in elite schools.

Outcomes assessment also has a long history, as the new form of standardization. It is part of an old dodge from the real problems with the American educational system: that it is embedded in an inequitable and violent socioeconomic system deliberately established by corporate powers. The kind of policies that would truly help the students with whom we work are not more hearings, campus visits, and testing, but adequate funding for secondary education; child care; a living wage; debt relief or, better yet, free universal post-secondary education; an adequately compensated academic workforce exercising free inquiry and building an educational community; and universal healthcare.

Many of us in higher education have experienced LOA first hand as a redirection of our resources and energy away from the needs of faculty and our students and towards a bloated bureaucratic system. Kamala Platt's experiences teaching in Texas represent those of several educators who contributed to a lively discussion of LOA on the MLA's Radical Caucus listserv, ${ }^{3}$ revealing that mandated assessment practices have harmful effects when "they corporatize the education process, molding both 
faculty and students to meet expectations created (often by those with little or no educational training) outside the classroom or even the Department" (Platt). In Texas, as in many states, the chief impetus for LOA is coming from right-wing members of the state legislature, Board of Education, and boards of trustees. Kamala notes that there is also a racialized component to the LOA movement, which attempts "to homogenize classrooms and curricula, and to marginalize those teachers or students who do not fit homogenization." And in practice, LOA procedures are also alienating for faculty who have to fill their syllabi with university-approved boilerplate and surrender autonomy over their classrooms in order to generate required material for externally "dictated student learning objectives." The LOA movement acts not on behalf of those it purports to help, but on behalf of the forces that seek to discipline and contain them. As Kathleen Kane puts it, LOA's "mode of address is upward, hierarchical, and focused on the bureaucratic."

The LOA movement is a danger to students because it pretends that their problems have more to do with easily quantifiable outcomes rather than with the need to create an environment conducive to truly engaged student learning through legitimate faculty-driven efforts at curriculum development and course evaluation. Through such misdirection, fetishizing LOA is likely to increase the inequities of higher education for students, who are increasingly bound to service their debt from graduation day to retirement age, confronted with curricula that come more and more to reflect the teaching-to-the-test model familiar to us from NCLB. Expending resources on assessment tools will only be used to show that students at rich schools do better on standardized measures than those who labor at poor schools. In the context of higher education, this finding will be particularly unfair because students in elite schools will by and large not be required to take standardized tests.

The LOA movement is a danger to teachers because it places us, and particularly those of us who are not tenured or not on tenure tracks, in service to a disciplinary mechanism that curtails academic freedom, places us at risk of unfair surveillance, and asks us to engage in further uncompensated or poorly compensated labor for dubious purposes. Conservative forces are using the LOA movement to blame teachers for the problems with U.S. higher education and put us on the defensive at a time when our energy needs to be focused on access, equality, and education. In an environment where more than twothirds of the teaching in colleges and universities is done by non-tenure-stream faculty, and where administrators outnumber full-time faculty on most campuses, all the best aspects of the academy-open inquiry, the tenure system, faculty self-governance-are under assault. For these reasons, we need to resist the institutionalization of the LOA movement-from the efforts of conservative think tanks and for-profit institutions to take over the accreditation process to right-wing efforts to attack tenure, teachers' unions and academic freedom while promoting standardization and corporatization.

We can resist, within our departments, by questioning the current wisdom that assessing learning outcomes should take priority over teaching our students how to think critically, including thinking critically about their own educations. We can ask our colleagues at meetings, "What really is the purpose of this focus on learning outcomes?" We can also embrace genuine departmentspecific assessment, what we used to call "curriculum development" and "course evaluation," whether through portfolios or other means. ${ }^{4}$ We can pressure accrediting bodies to recognize that institution-wide inputs are more relevant and controllable than outcomes. For example, radical teachers can talk with visiting accreditation teams and volunteer to be part of such teams or other outside assessment mechanisms to help push back against the LOA movement and foreground questions of inputs. We can work with political movements that advocate for what students, especially "at-risk" students, need most in order to be successful-debt relief, employment programs, healthcare, childcare. In short, we can embrace all that is sidetracked, undervalued, and underfunded because of the well-financed movement for phony forms of assessment.

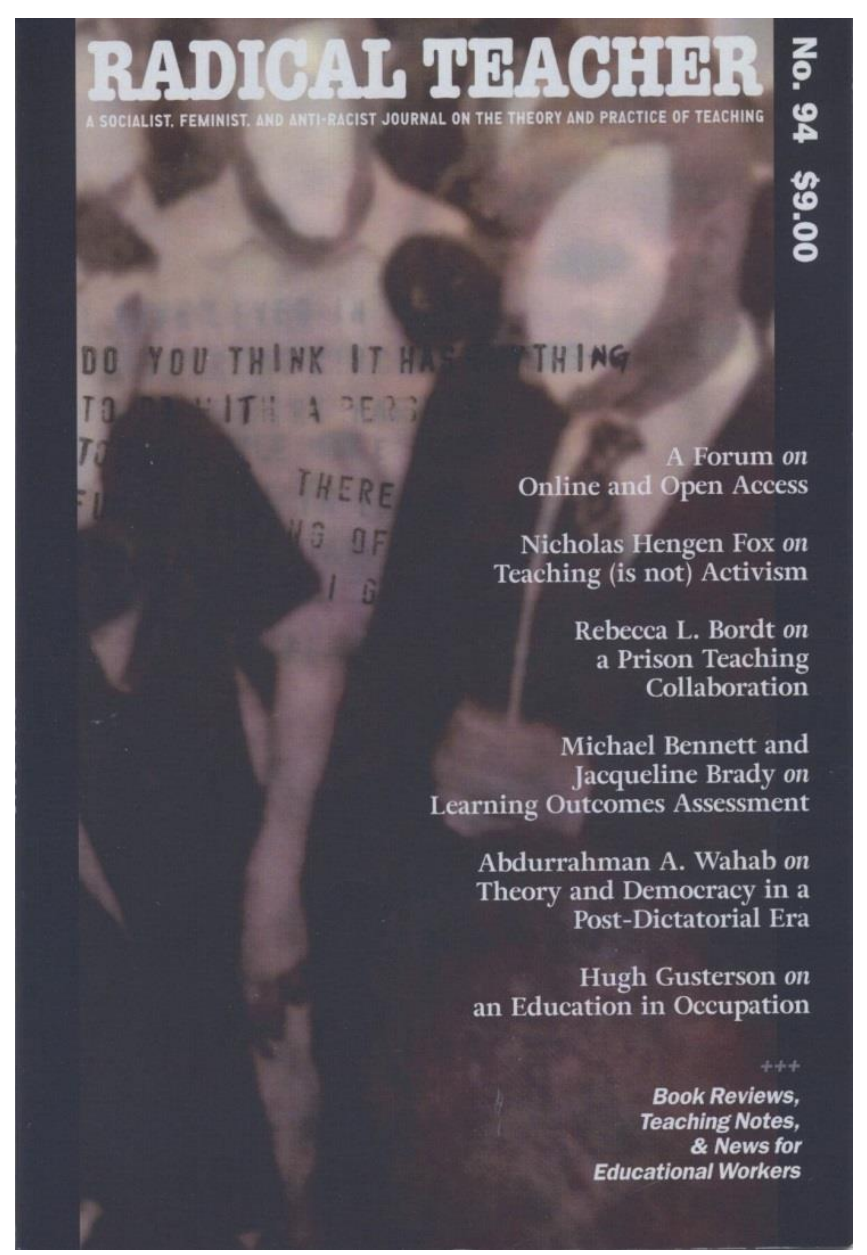




\section{NOTES}

${ }^{1}$ This discourse is everywhere in the professional LOA literature. See, for example, Peter Ewell, or really anything written by or for the National Center for Higher Education Management Systems (NCHEMS); Paul Gaston, one of several critics of LOA who nonetheless buys into much of the corporatist model; Jacobi, Astin, and Ayala, Jr.; and, in particular, the various publications by ACTA (www.goacta.org) and CED (www.ced.org).

${ }^{2}$ On how assessment tests in general, and the SAT in particular, end up measuring social class more than student potential, thus reinforcing inequality, see Lemann, Nairn, and Sacks.

${ }^{3}$ Learning Outcomes Assessment was a hot topic of conversation for several weeks on the discussion list of the Radical Caucus of the MLA (those readers who are members of the MLA and interested in joining the Radical Caucus may sign up at http://groups.google.com/group/radcaucus). We would especially like to thank the following individuals (some of whom we quote) for strengthening our critique of the LOA movement: James Berger, John Crawford, Barbara Foley, Grover Furr, Rich Gibson, Katie Kane, Marian Lupo, William Lyne, Sophia McClennen, Gregory Myerson, Dick Ohmann, Kamala Platt, David Siar, and Julia Stein. And thank you also to those who defended LOA-notably, Cathy Birkenstein-Graff and Steven Thomas-for likewise sharpening our analysis. And thanks as well to John Champagne, who shared a copy of his 2008 MLA talk on assessment and the corporate university.

${ }^{4}$ For example, at Michael Bennett's home institution (Long Island University's Brooklyn campus), departmental student evaluations and portfolios revealed the need for more instruction in accessing and using information from electronic databases, a task which we have embraced. But many of us also feel the need to resist the increasing institutionalization of what might be called the Assessment Industrial Complex, as witnessed by the growing administrative armature (including a Vice President of assessment) and seemingly endless demands for uncompensated labor in the form of email blasts, seminars, and other efforts to create an "assessment culture."

\section{WORKS CITED}

Bagley, William C. Classroom Management: Its Principles and Technique. New York: MacMillan. 1911.

Bobbit, Franklin. The Curriculum. Boston: Houghton Mifflin, 1918.

Eisner, Elliot. "Those Who Ignore the Past . . .? 12 'Easy' Lessons for the Next Millennium." Journal of Curriculum Studies. 32.2 (2000): 343357.

Ewell, Peter T. Accreditation and Student Learning Outcomes: A Proposed Point of Departure. Washington, D.C.: CHEA, 2001.

- - Information on Student Outcomes: How to Get It and How to Use It. Boulder, CO: NCHEMS, 1983.

Fair Test: The National Center for Fair and Open Testing Website. "High Stakes Testing Hurts Education." Accessed on March 22, 2010 http://www.fairtest.org/reports-high-stakes-testing-hurts-education.

Gaston, Paul T. "'Measuring the Marigolds': Literary Studies and the Opportunity of Outcomes Assessment." The Journal of the Midwest Modern Language Association 24.2 (Autumn 1991): 11-20.
Graff, Gerald. "Assessment Changes Everything." MLA Newsletter 40.1 (2008): 3-4.

Hussey, Trevor and Patrick Smith. "Learning Outcomes: a Conceptual Analysis." Teaching in Higher Education.13.1 February (2008): 107115 .

- - "The Uses of Learning Outcomes." Teaching in Higher Education. 8.3 (2003): 357-368.

Jacobi, Maryann, Alexander Astin, and Frank Ayala, Jr. College Student Outcomes Assessment: A Talent Development Perspective. Washington, D.C.: ASHE-ERIC, 1987.

Kane, Kathleen. Email correspondence. 26 February 2008.

Leef, George C. and Roxana D. Burris. Can College Accreditation Live Up to its Promise? Washington, D.C.: ACTA, 2002.

Lemann, Nicholas. The Big Test: The Secret History of the American Meritocracy. NY : Farrar, Straus and Giroux, 2000.

Miner, Barbara. "Testing Companies Mine for Gold." Rethinking Schools. Winter2004/2005.

<http:www.rethinkingschools.org/special_reports/bushplan/test/92.sh tml>

Nairn, Allan. The Reign of ETS: The Corporation That Makes Up Minds. Ralph Nader, 1980.

The National Institute for Learning Outcomes Assessment Website. $\begin{array}{llll}\text { Accessed } & 23 & 2012 .\end{array}$

http://www.learningoutcomeassessment.org.

Petri, Thomas E. Hearings of the House Subcommittee on 21st-Century Competitiveness of the Committee of Education and the Workforce. 107th Congress, Second Session. 1 October 2002.

Platt, Kamala. Email correspondence. 14 January 2012.

Pontuso, James F. and Sarranna R. Thornton. "Is Outcomes Assessment Hurting Higher Education?" Thought \& Action: The NEA Higher Educational Journal. Fall (2008): 61-69.

Sacks, Peter. Standardized Minds: The High Price of America's Testing Culture and What We Can Do to Change It. Cambridge, MA: Perseus, 1999. 